\title{
KARAKTERISTIK SEDIMEN HOLOSEN - PLEISTOSEN BERDASARKAN UKURAN BUTIR PADA SEDIMEN INTI EW17-08, TEPI BARATLAUT PAPARAN SUNDA
}

\author{
Septriono Hari Nugroho ${ }^{1}$, Purna Sulastya Putra ${ }^{1}$, Ageng Digdya Garin Pamungkas ${ }^{2}$ \\ ${ }^{1}$ Pusat Penelitian Geoteknologi, Lembaga Ilmu Pengetahuan Indonesia (LIPI) \\ ${ }^{2}$ Alumni Program Studi Teknik Geologi, Fakultas Ilmu dan Teknologi Kebumian, Institut Teknologi Bandung \\ e-mail: sept006@lipi.go.id
}

\begin{abstract}
Abstrak. Sedimen inti EW17-08 terletak pada tepi baratlaut Paparan Sunda. Pengendapan sedimen pada wilayah tersebut berhubungan dengan perubahan kenaikan permukaan laut yang terjadi pada paparan Sunda. Penelitian ini merupakan studi pendahuluan yang bertujuan untuk mengetahui karakterstik sedimen berdasarkan analisis kecenderungan ukuran butir pada periode transisi Holosen - Pleistosen. Sedimen inti EW17-08 diambil menggunakan Kapal Riset BJ VIII yang merupakan bagian dari Ekspedisi Widya Nusantara. Karakteristik sedimen Holosen dan Pleistosen dapat dibedakan dari nilai mean, sortasi, skewness dan kurtosis. Batas Holosen - Pleistosen ditentukan berdasarkan kemunculan pertama dari Bolliela Adamsi pada kedalaman $161 \mathrm{~cm}$. Fasies sedimen dalam inti tersebut dibedakan menjadi dua fasies, fasies I berumur Pleistosen Akhir dengan komposisi sedimen berupa perselingan lanau sedangpasir sangat halus. Fasies II dengan komposisi sedimen berupa lanau kasar dan berumur Holosen. Hasil studi pendahulan ini diharapkan dapat digunakan untuk mengetahui perubahan lingkungan yang terjadi selama Pleistosen - Holosen.
\end{abstract}

Kata Kunci: sedimen; karakteristik; ukuran butir; batas Pleistosen - Holosen.

\begin{abstract}
The core sediment EW17-08 located in the northwestern margin of the Sunda Shelf. Sediment deposition in this area related to changes in sea level rise that occured in Sunda Shelf. This preliminary research aims to determine sediments characteristics based on grainsize trend analysis in the PleistoceneHolocene boundary. The sediment core of EW17-08 was taken by using Research Vessel BJ VIII which is a part of Widya Nusantara Expedition. The characteristics of between Pleistocene and Holocene sediments can be distinguished by mean, sorting, skewness and kurtosis values. The Holocene - Pleistocene boundary was determined by the first appearance of Bolliela Adamsi at depth of $161 \mathrm{~cm}$. Sedimentary facies in the core can be divided into two facies, facies I consist of alternating layers medium silt and very fine sand in Late Pleistocene. Faces II composited by coarse silt in Holocene. These preliminary results are expected to be used to determine environmental changes during the Pleistocene-Holocene.
\end{abstract}

Keywords: sedimen; characteristic; grain size; Pleistocene - Holocene boundary.

\section{PENDAHULUAN}

Secara temporal maupun spasial, perubahan karakteristik sedimen menjadi hal penting dalam rekonstruksi pengendapan sedimen (Miall, 2010; $\mathrm{H}$. W. Posamentier dan Kolla, 2003). Iklim, geomorfologi, maupun kondisi dan proses geologi yang lainnya mempengaruhi komposisi sedimen laut (Zuraida dkk., 2018). Stratigrafi dari sistem Paparan dihasilkan dari interaksi antara sejumlah faktor pada skala umum dan lokal (T. J. J Hanebuth dan Stattegger, 2004). Perubahan permukaan laut relatif (berdasarkan eustasi global dan tektonik) menambah atau mengurangi ruang akomodasi. Kondisi morfologis menentukan pola sedimentasi dan erosi selanjutnya. Proses iklim mengontrol input sedimen berdasarkan jenis dan oleh intensitas pelapukan, laju erosi dan volume sedimen (T. J. J Hanebuth dan Stattegger, 2004). Faktor tambahan sering kali terbatas secara lokal (misal pasang surut, gelombang, badai, kelimpahan tutupan vegetasi) juga memainkan peran penting dalam pengembangan geometri deposenter selama fase konstruktif dan destruktif (T. J. J Hanebuth dan Stattegger, 2004). Selain itu, proses autogenik seperti pergeseran lateral segmen aliran sungai atau perbedaan laju pemadatan mengubah pola pengendapan. Analisis sistem Paparan harus memperhitungkan perbedaan yang signifikan antara proses, yang membentuk endapan, dan rekaman sedimen yang diawetkan, yang hanya mewakili 
sebagian dari sejarah sedimentasi yang sebenarnya (Henry W. Posamentier dan Allen, 1993; P. Vail, 1991). Konsep urutan stratigrafi dikembangkan pada tahun 1980-an memungkinkan korelasi dan prediksi lingkungan pengendapan yang berbeda $(\mathrm{H}$. W. Posamentier dan Vail, 1988; P. R. Vail, 1987). Diskusi baru-baru ini pada model urutan stratigrafi berfokus pada fitur spesifik, yang bervariasi untuk setiap sistem paparan (Hunt dan R. L. Gawthorpe, 2000; Miall, 2000; Henry W. Posamentier dan Allen, 1993).

Paparan Sunda merupakan salah satu contoh terbaik yang menunjukkan susunan stratigrafi dan potensi untuk menyimpan dan melepaskan sedimen dari waktu ke waktu (T. J. J Hanebuth dan Stattegger, 2004). Pembentukan Paparan Sunda dipengaruhi oleh perubahan iklim masa lalu, khususnya pada batas Pleistosen-Holosen, dan perubahan permukaan laut masa lalu (Van Welzen dkk., 2011). Selain itu, fluktuasi permukaan laut juga sangat berdampak pada posisi garis pantai dan susunan stratigrafi. Penelitian sejarah kondisi permukaan laut sekitar Paparan Sunda sejak Zaman Es Terakhir (Last Glacial Maksimum - LGM) telah dilakukan oleh (Geyh dkk., 1979; null Hanebuth dkk., 2000; T. J. J. Hanebuth dkk., 2009; Till J. J. Hanebuth dkk., 2011; Hesp dkk., 1998; Tjia, 1996). Namun, kurangnya rekaman data fluktuasi kondisi permukaan laut dan perubahan lingkungan selama kurun waktu Holosen Tengah - Akhir dengan kualitas data yang baik menyebabkan tidak terdefinisikannya secara jelas besaran posisi permukaan laut pada saat Holosen Tengah. Kekurangan data itu memunculkan debat mengenai kebenaran Holosen maksimum pada periode Holosen Tengah yang berakibat pada perbedaan kejadian highstand di wilayah ini (Bird dkk., 2007; Briggs dkk., 2008; Horton dkk., 2016). Selain itu, bukti perubahan lingkungan yang terekam pada sedimen laut berdasarkan karakteristik sedimen dan kandungan foraminifera pada periode transisi Pleistosen dan Holosen masih belum banyak dipelajari.

Studi pendahuluan ini bermaksud untuk membandingkan karakteristik distribusi sedimen untuk membedakan Kala Pleistosen dan Holosen di tepi barat-laut Paparan Sunda melalui pengamatan ukuran butir dan kandungan foraminifera menggunakan metode analisis kecenderungan perubahan ukuran butir (Grain size trend analysis GSTA) dan analisis foraminifera. GSTA biasa digunakan untuk membedakan karakter fisik dan tekstural yang berfungsi untuk mengetahui transportasi dan pengendapan sedimen (Nugroho dan Putra, 2018). Beberapa penelitian tentang distribusi sedimen memberikan informasi sumber sedimen, transportasi dan pengendapan sedimen

(Angusamy dan Rajamanickam, 2006; Nugroho, S. H., 2014; Nugroho, 2013; Nugroho dan Putra, 2018). Parameter ukuran butir tersebut digunakan baik di lingkungan pengendapan modern maupun masa lalu (Gandhi dkk., 2008; IRUDHAYANATHAN dkk., 2011; Malvarez dkk., 2001; Ramamohanarao dkk., 2003; Ramanathan dkk., 2009). Selain dengan karakteristik ukuran butir, kondisi lingkungan dapat direfleksikan oleh kandungan foraminifera. Kumpulan spesies tersebut mewakili kondisi lingkungan tertentu di suatu wilayah (Kirci-Elmas, 2013; Lutze dan Coulbourn, 1984; Phleger, 1973; Saraswat, 2015; Sengupta, 1977). Oleh karena itu, variasi temporal pada kumpulan taksa foraminifera tersebut diterapkan untuk menyimpulkan variasi kondisi lingkungan dan merupakan salah satu proksi foraminifera yang paling banyak digunakan untuk menyimpulkan variasi iklim bumi (Gupta dan Thomas, 2003). Dengan analisis ukuran butir dan foraminifera, studi pendahuluan ini diharapkan dapat menambah pengetahuan tentang perubahan iklim dan lingkungan yang terjadi di wilayah tepi barat laut Paparan Sunda.

\section{METODOLOGI}

Sampel penelitian ini telah diambil di Samudra Indonesia selama Ekspedisi Widya Nusantara (EWIN) pada Desember 2017 menggunakan gravity corer pada Kapal Riset Baruna Jaya VIII. Sampel sedimen EW17-08 (02 29'47" LU dan 94 46'43" BT, kedalaman laut $2811 \mathrm{~m}$, Gambar 1) dengan panjang $223 \mathrm{~cm}$ dan dipotong dengan interval satu $\mathrm{cm}$ 
sehingga diperoleh 223 sub-sampel sedimen yang belum terkonsolidasi.

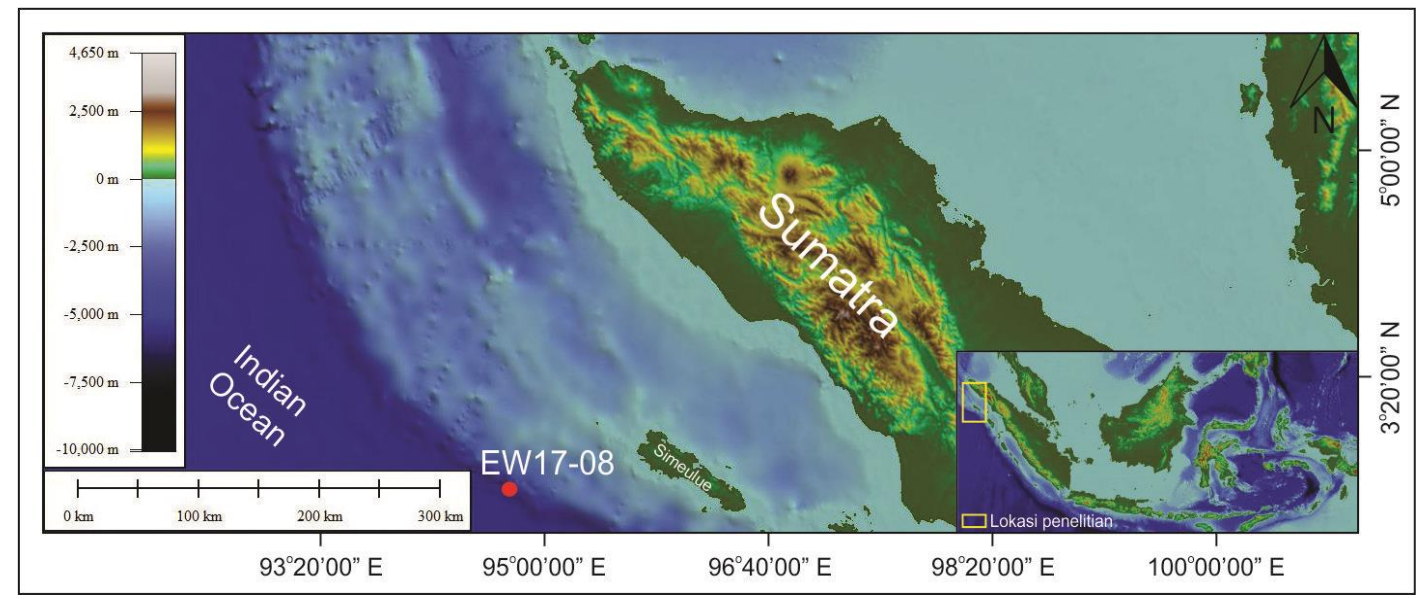

Gambar 1. Peta Lokasi Inti sedimen EW 17-08 yang terletakdi tepian baratlaut Paparan Sunda

Malvern Mastersizer 2000 digunakan dalam analisis besar butir yang dilakukan di Laboratorium Sedimentologi, Pusat Penelitian Geoteknologi LIPI, Bandung. Alat tersebut mengukur besar butir dengan kisaran butir diantara 0,02 $\mu \mathrm{m}$ sampai 2000 $\mu \mathrm{m}$. Masing-masing sampel diperlukan sekitar $2 \mathrm{gr}$ untuk proses pemisahan ukuran butir. Selanjutnya hasil pengukuran ukuran butir diolah menggunakan perangkat lunak Gradistat v.4.0 (Blott dan Pye, 2001) untuk menghasilkan parameter statistik berupa mean, skewness, kurtosis dan sortasi dengan menggunakan metode geometri (Folk dan Ward, 1957). Parameter tersebut digunakan sebagai pendekatan untuk menentukan sistem transportasi sedimen (Folk dan Ward, 1957). Putra dan Nugroho (2017) dalam papernya menjelaskan bahwa masingmasing parameter tersebut dapat menceritakan kondisi sedimen pada saat mengalami transportasi dan pengendapan. Mekanisme transportasi sedimen dapat diketahui dengan membuat diagram CM (Passega, 1964; Passega dan Byramjee, 1969; Visher, 1969). C merupakan nilai persentil pertama (D90) sedangkan $\mathrm{M}$ adalah nilai median, keduanya diperoleh dari perhitungan statistik menggunakan Gradistat 4.0 dalam satuan micron $(\mu \mathrm{m})$. Selanjutnya untuk mengetahui proses dan laju pengendapan sedimen sepanjang pantai dilakukan analisis Stewart (Harris B. Stewart, 1958). Diagram Stewart membandingkan nilai median dan sortasi dalam satuan phi.

Analisis foraminifera dipreparasi menggunakan air dengan teknik swirling (Sukapti, 2016) agar sedimen terpisah dengan foraminifera. Metode tersebut digunakan karena sampel belum terkonsolidasi sehingga cukup menggunakan metode tersebut (Putra dan Nugroho, 2020). Sampel selanjutnya disaring dengan ukuran bukaan 100 mesh. Pengeringan sampel dilakukan pada suhu $80{ }^{\circ} \mathrm{C}$ selama 15 menit menggunakan oven, kemudian sub-sampel dipisahkan dengan setidaknya 300 spesimen seluruh foraminifera, yang diidentifikasi dan dihitung. Proses penjentikan (picking) dilakukan menggunakan mikroskop pada setiap sampel. Identifikasi dilakukan dengan mengamati morfologi cangkang yang mencakup bentuk cangkang, jumlah kamar, apertur, dan komposisi penyusun cangkang. Katalog foraminifera yang digunakan dalam studi ini adalah (Adisaputra dkk., 2010; Holbourn dkk., 2013; Postuma, 1971). Distribusi biogeografi foraminifera digunakan untuk mendukung penentuan karakteristik perubahan lingkungan dan iklim pada periode tertentu. Klasifikasi yang digunakan pada penentuan distribusi biogeografi berdasarkan (Boltovskoy, 1969).

\section{HASIL DAN PEMBAHASAN}

\section{Analisis Foraminifera}

Berdasarkan analisis foraminifera planktonik yang dilakukan pada sampel inti sedimen EW17-08, ditemukan kemunculan pertama (First Appereance Datum/FAD) spesies foraminifera planktonik Bolliella adamsi pada kedalaman $161 \mathrm{~cm}$ (Gambar 2). 


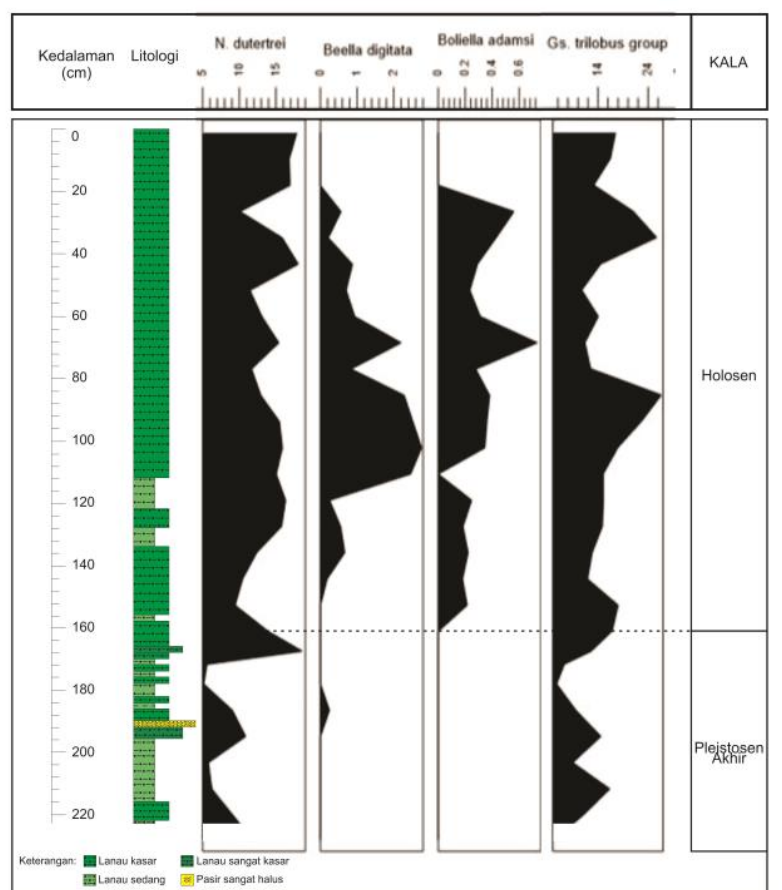

Gambar 2. Kumpulan spesies foraminifera penciri distribusi biogeografi dan kemunculan pertama Bolliella adamsi yang dianggap sebagai spesies penunjuk awal Holosen (Bolli dkk., 1989). Garis putus-putus menunjukkan batas Pleistosen - Holosen.

Menurut (Bolli dkk., 1989; Coxall dkk., 2007), pemunculan awal Bolliella adamsi merupakan spesies penunjuk awal Holosen (N23) sehingga dapat disimpulkan bahwa sedimen pada kedalaman 0 - $161 \mathrm{~cm}$ berumur Holosen dan sedimen pada kedalaman 161 - $223 \mathrm{~cm}$ berumur Pleistosen Akhir. Selain itu, hal tersebut juga ditunjukkan oleh distribusi biogeografi foraminifera planktonik (Gambar 2) yang menunjukkan peningkatan spesies N. dutertrei, Beella digitata, Boliella adamsi yang pada umumnya hidup dan terdapat secara melimpah pada perairan laut yang hangat (lintang rendah) pada kedalaman $0-161 \mathrm{~cm}$. Kondisi tersebut diinterpratasikan bahwa kondisi iklim Kala Holosen yang lebih hangat dibandingkan Pleistosen (Morley, 1982; Newsome dan Flenley, 1988).

Secara umum, besar butir sedimen inti EW1708 didominasi oleh ukuran butir lanau. Karakteristik sedimen tersebut dikelompokkan menjadi dua fasies yaitu fasies I (perselingan lanau sedang-pasir sangat halus) dan fasies II (lanau kasar) (Gambar 3). Analisis statistik dilakukan untuk mengetahui parameter ukuran butir seperti mean, sortasi, skewness, dan kurtosis. Fasies tersebut diinterpretasikan mencirikan adanya perubahan lingkungan dan iklim yang ditunjukkan oleh sebaran ukuran butir yang berbeda pada setiap periode. Pada bagian bawah, ukuran butir relatif lebih bervariasi yaitu perselingan lanau lanau sedang pasir sangat halus. Sementara itu pada bagian atas, ukuran butir relatif lebih seragam dan didominasi oleh lanau kasar.

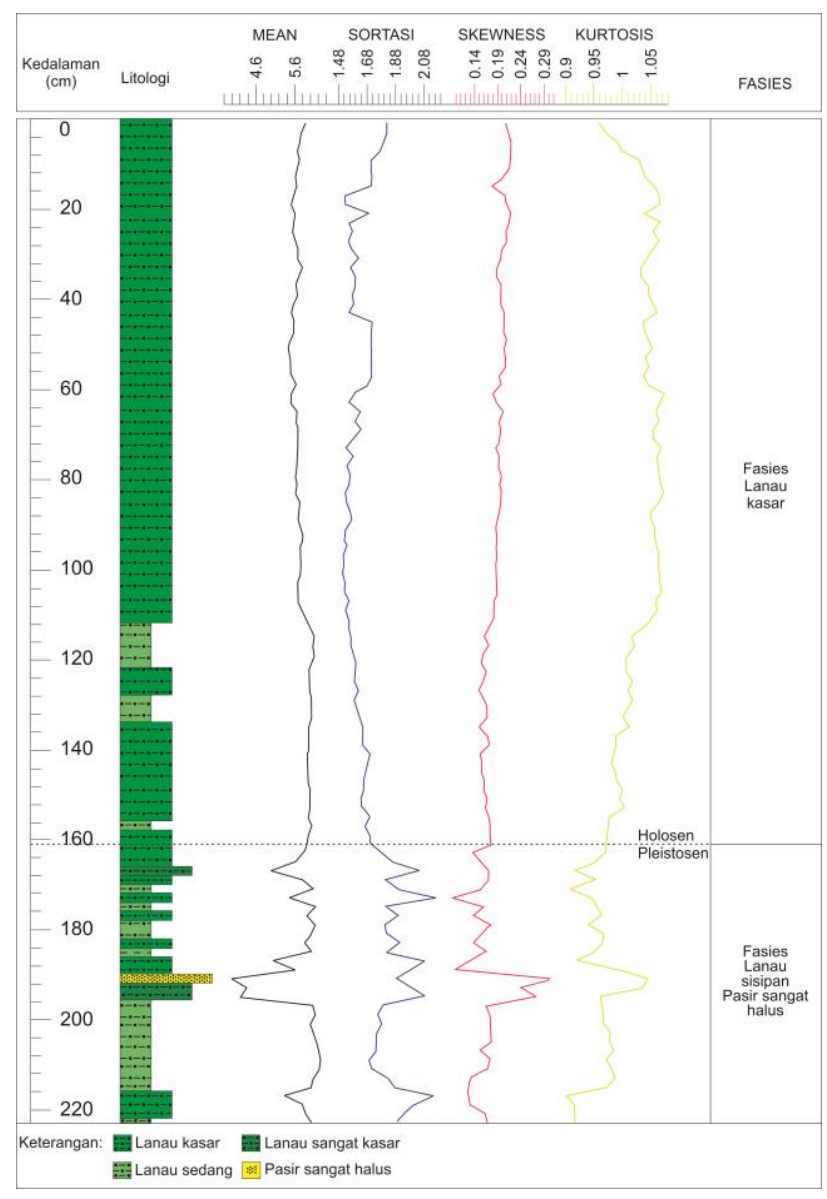

Gambar 3. Kolom litologi dan parameter statistik EW1708. Garis putus-putus menunjukkan batas Pleistosen Holosen.

Fasies I (Gambar 3) terdiri atas lanau dengan sisipan pasir sangat halus, kedalaman $223-161 \mathrm{~cm}$, memiliki nilai parameter ukuran butir yaitu mean bernilai antara 3,970 phi (pasir sangat halus) - 6,093 phi (lanau sedang). Nilai sortasi yang didapatkan berkisar antara 1,555 - 1,865 phi yang termasuk dalam klasifikasi poorly - very poorly sorted. Nilai skewness yang didapatkan berkisar antara 0,136 0,175 phi yang termasuk dalam klasifikasi fine skewed. Nilai kurtosis yang didapatkan berkisar 
antara 0,953 - 1,047 phi yang termasuk dalam klasifikasi mesokurtic.

Fasies II (Gambar 3) terdiri dari lanau kasar, kedalaman $161-0 \mathrm{~cm}$ memiliki nilai mean yang nilainya berkisar antara 5,441 - 6,093 phi yang termasuk dalam klasifikasi lanau sedang sampai kasar. Nilai sortasi yang didapatkan berkisar antara 1,511 - 1,865 phi yang termasuk dalam klasifikasi poorly sorted. Nilai skewness yang didapatkan berkisar antara 0,150 - 0,219 phi yang termasuk dalam klasifikasi fine skewed. Nilai kurtosis yang didapatkan berkisar antara 0,953-1,074 phi yang termasuk dalam klasifikasi mesokurtic.

\section{Bivariate plot}

Grafik hubungan mean besar butir dan sortasi pada sedimen EW17-08 ditunjukkan Gambar 4a. Berdasarkan grafik tersebut, didapatkan bahwa sedimen fasies II memiliki karakteristik yang berbeda dengan sedimen yang berumur fasies $\mathrm{I}$. Sedimen fasies II cenderung mengelompok pada kategori lanau sedang hingga kasar dengan sortasi buruk. Sementara itu, sedimen fasies I cenderung menyebar pada kategori lanau sedang hingga pasir sangat halus dengan sortasi buruk hingga sangat
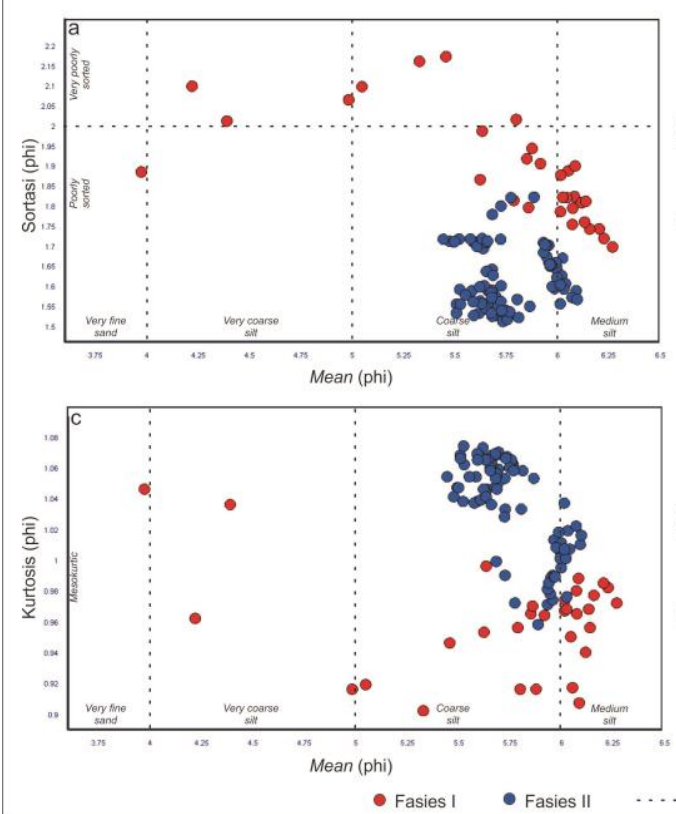

buruk. Sementara itu, hubungan mean vs skewness pada sedimen EW17-08 ditunjukkan pada Gambar 4b. Grafik tersebut menunjukkan sedimen fasies II menunjukkan nilai skewness yang mengelompok pada kategori kategori fine skewed. Sementara itu, skewness sedimen fasies I cenderung menyebar pada kategori very fine skewed hingga symmetrical. Hubungan mean vs kurtosis pada EW17-08 ditunjukkan pada Gambar 4c. Berdasarkan grafik tersebut, sedimen fasies II memiliki karakteristik yang berbeda dengan sedimen yang berumur fasies I. Nilai kurtosis sedimen fasies II dan fasies I termasuk dalam kategori mesokurtic, akan tetapi memiliki pola sebaran yang berbeda. Pola sebaran nilai kurtosis fasies I lebih mengelompok dibandingkan pola kurtosis fasies I yang menyebar. Sementara itu, Gambar 4d menunjukkan hubungan sortasi besar butir dan skewness pada sedimen EW17-08. Grafik tersebut menggambarkan sedimen fasies II cenderung mengelompok pada kategori fine skewed dengan sortasi buruk, sedangkan sedimen fasies I cenderung menyebar pada kategori very fine skewed hingga symmetrical dengan sortasi buruk hingga sangat buruk.

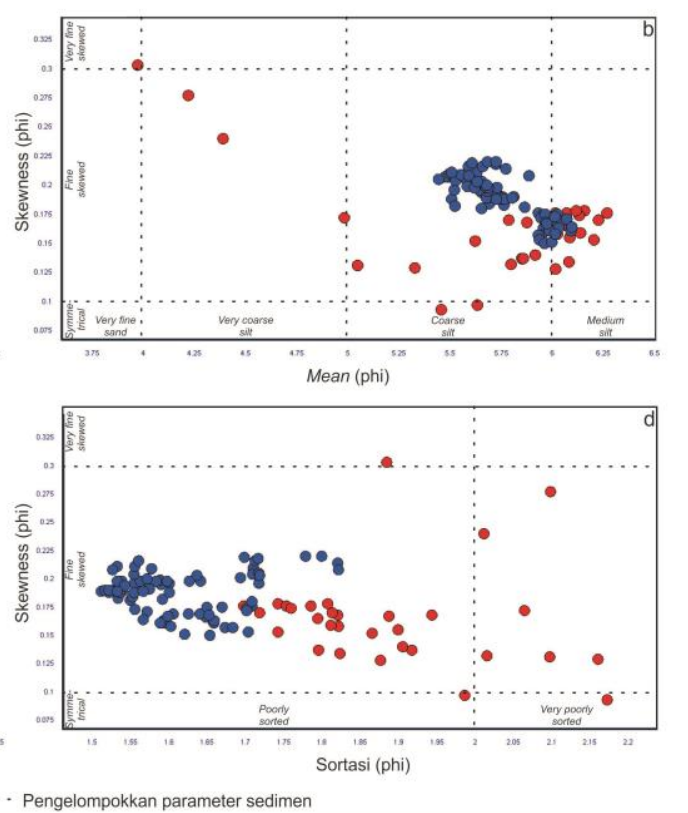

Gambar 4. Grafik bivariate plot yang menunjukkan hubungan mean dan sortasi (a), mean dan skewness (b), mean dan kurtosis (c), sortasi dan skewness. Pengelompokkan parameter statistik sedimen berdasarkan (Blott dan Pye, 2001).

Berdasarkan data hasil analisis besar butir yang telah diplot dalam diagram bivariate, terlihat adanya perbedaan kecenderungan karakteristik sedimen masing-masing fasies pada Kala Pleistosen 
dan Holosen. Hal tersebut dapat menunjukkan kondisi perubahan lingkungan dan iklim pada suatu periode waktu (T. J. J Hanebuth dan Stattegger, 2004). Fasies I yang memiliki pola menyebar dibandingkan fasies II, menunjukkan kondisi iklim Pleistosen yang lebih fluktuatif dan variatif. Sementara itu, ukuran butir yang beragam dan cenderung lebih kasar menunjukkan proses transportasi yang berubah-ubah, kemungkinan akibat adanya naik-turun kondisi permukaan laut yang signifikan pada Kala Pleistosen. Kondisi tersebut menyebabkan sortasi pada fasies I buruk hingga sangat buruk. Variasi dari nilai kurtosis EW17-08 menunjukkan adanya pengaruh karakteristik aliran dari media yang membawa sedimen, seperti yang disampaikan (Ray dkk., 2006). Menurut (Cadigan, 1961) Sedimen bersortasi buruk memiliki nilai kurtosis yang semakin terpancung. Skewness berhubungan dengan energi pengendapan, sebagaimana yang disampaikan (McLaren dan Bowles, 1985), bahwa nilai skewness dari highly negative skewness menjadi mendekati simetris menunjukkan adanya kenaikan energi dalam proses transportasi sedimen. Kandungan partikel berukuran lebih kasar memiliki nilai kurtosis positif (Putra dan Nugroho, 2017, hal.200). Sehingga energi pengendapan pada kedua fasies tersebut termasuk dalam kategori rendah, karena memiliki ukuran butir relatif halus.

\section{Diagram C-M dan Stewart}

(Passega, 1964) menunjukkan bahwa nilai median dan persentil pertama menggambarkan mekanisme pengendapan yang terjadi baik di fasies I maupun II yang ditunjukkan pada diagram CM (Gambar 5a). Mekanisme pengendapan sangat erat hubungannya dengan ukuran butir. Pada fasies I mekanisme pengendapan terjadi melalui proses pelagic suspension - uniform suspension, hal tersebut terjadi pada sedimen yang berukuran relatif kasar dan variatif (Gambar 5a). Sementara itu, fasies II diendapkan melalui mekanisme sedimentasi didominasi dengan proses pelagic suspension (Gambar 4a). Hasil diagram C-M pada sedimen EW17-08 memiliki kesamaan dengan hasil penelitian (Nugroho dkk., 2018), sedimen permukaan yang diendapkan dengan mekanisme pelagic suspension. Sementara itu penelitian (Putra dan Nugroho, 2017), (Zulhikmah dkk., 2020) yang dilakukan di Perairan Sumba, sedimen permukaanya diendapkan dengan mekanisme uniform suspension. Ketiganya memiliki kesamaan yaitu sama-sama diendapakan pada laut dalam dengan variasi bathymetri yang sama.

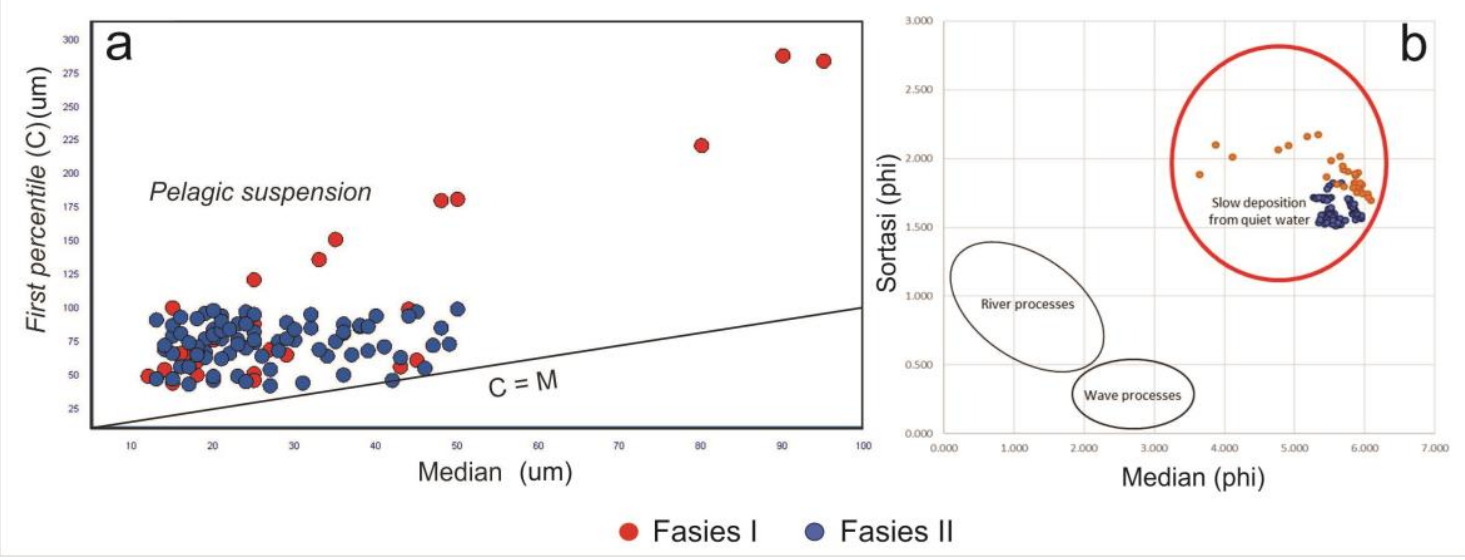

Gambar 5. a. Mekanisme pengendapan yang ditunjukkan pada diagram C-M (modifikasi dari Passega, 1964). b. Hubungan sortasi dan median memperlihatkan kondisi pengendapan lambat dan tenang (dimodifikasi dari Stewart, 1958). Lingkaran merah menunjukkan kondisi pengendapan pada wilayah studi.

Analisis hubungan antara median dan sortasi menggambarkan terjadinya pengendapan yang tenang dan perlahan (slow deposition from quiet waters) (Gambar 5b). Hal tersebut menggambarkan 
kondisi pengendapan yang terjadi di laut dalam, yaitu pengendapan material berbutir halus terjadi secara perlahan dengan kondisi yang relatif tenang. Kondisi tersebut normal terjadi pada pengendapan sedimen laut, sebagaimana penelitian yang dilakukan oleh (Nugroho dkk., 2018; Putra dan Nugroho, 2017; Suryantini dkk., 2011; Zulhikmah dkk., 2020), mengidentifikasi pengendapan sedimen dasar laut Karimun Jawa, Perairan Sumba, Perairan Tarakan, dan Selat Sumba terjadi secara perlahan dan tenang.

\section{PENUTUP}

\section{Simpulan dan Saran}

Studi pendahuluan dengan hasil analisis sedimen dan analisis foraminifera pada inti EW1708, dapat disimpulkan sebagai berikut:

1. Fasies I, diperkirakan berumur relatif Pleistosen Akhir, komposisi sedimen berupa lanau dengan sisipan pasir sangat halus, mean bernilai antara 3,970-6,093, sortasi buruk - sangat buruk, very fine skewed - symmetrical, mesokurtic. Mekanisme pengendapan yang terjadi adalah proses pelagic suspension - uniform suspension pada perairan yang tenang dan pelan. Kehadiran spesies $N$. dutertrei, Beella digitata, Boliela adamsi, Gs. Trilobus rendah bahkan tidak muncul.

2. Fasies II, diperkirakan berumur relatif Holosen dengan komposisi sedimen berupa lanau kasar, nilai mean antara 5,441 - 6,093, sortasi buruk, fine skewed, mesokurtic. Mekanisme sedimentasi didominasi oleh proses pelagic suspension pada perairan yang tenang dan pelan. Spesies $\mathrm{N}$. dutertrei, Beella digitata, Boliela adamsi, Gs. Trilobus mengalami peningkatan dibandingkan fasies lainnya.

Saran untuk penelitian selanjutnya perlu dilakukan analisis penanggalan absolut, sehingga diperoleh umur dan kecepatan laju pengendapan.

\section{Ucapan Terima Kasih}

Penelitian ini sebagai bagian dari Ekspedisi Widya Nusantara (EWIN) 2017. Penulis mengucapkan terima kasih kepada Kepala Pusat
Penelitian Oseanografi, Dr. Aan J. Wahyudi dan Nurul Fitriya, M.Si atas kesempatan mengikuti kegiatan ekspedisi tersebut. Penulis juga mengucapkan terima kasih kepada Nakhoda dan ABK BJ VIII yang telah membantu dalam proses pengambilan data. Ucapan terima kasih juga kami sampaikan untuk Sdr. Singgih Prasetyo Adi Wibowo, AMd selaku teknisi geologi yang telah banyak membantu selama ekpsedisi berlangsung.

\section{Kontribusi Penulis}

SHN sebagai kontributor utama bekontribusi membuat konsep, menyiapkan dan menulis paper ini. PSP berkontribusi memberikan saran, masukan dan mengedit tulisan. ADGP memberikan kontribusi dalam pekerjaan laboratorium dan pengolahan data. SHN dan PSP mengikuti ekspedisi EWIN dan mengambil sampel.

\section{DAFTAR PUSTAKA}

Adisaputra, M.K., Hendrizan, M. dan Kholiq, A. (2010), Katalog foraminifera perairan Indonesia, Kementerian Energi dan Sumber Daya Mineral, Badan Litbang Energi dan Sumber ....

Angusamy, N. dan Rajamanickam, G.V. (2006), Depositional Environment of Sediments along the Southern Coast of Tamil Nadu, India, hal. 16.

Bird, M.I., Fifield, L.K., Teh, T.S., Chang, C.H., Shirlaw, N. dan Lambeck, K. (2007), "An Inflection in the Rate of Early Mid-Holocene Eustatic Sea-Level Rise: A New Sea-Level Curve from Singapore", Estuarine, Coastal and Shelf Science, Vol.71, No.3, hal. 523-536. http://doi.org/10.1016/j.ecss.2006.07.004.

Blott, S.J. dan Pye, K. (2001), "GRADISTAT: A Grain Size Distribution and Statistics Package for the Analysis of Unconsolidated Sediments", Earth Surface Processes and Landforms, Vol.26, No.11, hal. 1237-1248. http://doi.org/10.1002/esp.261.

Bolli, H.M., Saunders, J.B., Perch-Nielsen, K. dan Fancett, K.E. (1989), Plankton Stratigraphy. Volume 1, Volume 1, Cambridge university press, Cambridge.

Boltovskoy, E. (1969), "Living Planktonic Foraminifera at the $90^{\circ} \mathrm{E}$ Meridian from the Equator to the Antarctic", Micropaleontology, Vol.15, No.2, hal. 237-255. http://doi.org/10.2307/1484923.

Briggs, R.W., Sieh, K., Amidon, W.H., Galetzka, J., Prayudi, D., Suprihanto, I., Sastra, N., 
Suwargadi, B., Natawidjaja, D. dan Farr, T.G. (2008), "Persistent Elastic Behavior above a Megathrust Rupture Patch: Nias Island, West Sumatra", Journal of Geophysical Research: Solid Earth, Vol.113, No.B12. http://doi.org/10.1029/2008JB005684.

Cadigan, R.A. (1961), "Geologic Interpretation of GrainSize Distribution Measurements of Colorado Plateau Sedimentary Rocks", The Journal of Geology, Vol.69, No.2, hal. 121-144. http://doi.org/10.1086/626724.

Coxall, H.K., Wilson, P.A., Pearson, P.N. dan Sexton, P.F. (2007), "Iterative Evolution of Digitate Planktonic Foraminifera", Paleobiology, Vol.33, No.4, hal. 495-516. http://doi.org/10.1666/06034.1.

Folk, R.L. dan Ward, W.C. (1957), "Brazos River Bar [Texas]; a Study in the Significance of Grain Size Parameters", Journal of Sedimentary Research, Vol.27, No.1, hal. 3-26. http://doi.org/10.1306/74D70646-2B21-11D78648000102C1865D.

Gandhi, M.S., Solai, A., Chandrasekaran, K. dan Rammohan, V. (2008), Sediment Characteristics and Heavy Mineral Distribution in Tamiraparani Estuary and Off Tuticorin, Tamil Nadu- SEM Studies, hal. 17.

Geyh, M.A., Streif, H. dan Kudrass, H.-R. (1979), "SeaLevel Changes during the Late Pleistocene and Holocene in the Strait of Malacca", Nature, Vol.278, No.5703, hal. 441-443. http://doi.org/10.1038/278441a0.

Gupta, A.K. dan Thomas, E. (2003), "Initiation of Northern Hemisphere Glaciation and Strengthening of the Northeast Indian Monsoon: Ocean Drilling Program Site 758, Eastern Equatorial Indian Ocean", Geology, Vol.31, No.1, hal. 47-50. http://doi.org/10.1130/00917613(2003)031<0047:IONHGA>2.0.CO;2.

Hanebuth, null, Stattegger, null dan Grootes, null (2000), "Rapid Flooding of the Sunda Shelf: A Late-Glacial Sea-Level Record", Science (New York, N.Y.), Vol.288, No.5468, hal. 1033-1035. http://doi.org/10.1126/science.288.5468.1033.

Hanebuth, T. J. J dan Stattegger, K. (2004), "Depositional Sequences on a Late Pleistocene-Holocene Tropical Siliciclastic Shelf (Sunda Shelf, Southeast Asia)", Journal of Asian Earth Sciences, Vol.23, No.1, hal. 113-126. http://doi.org/10.1016/S1367-9120(03)001007.

Hanebuth, T. J. J., Stattegger, K. dan Bojanowski, A. (2009), "Termination of the Last Glacial Maximum Sea-Level Lowstand: The Sunda-Shelf Data Revisited", Global and Planetary Change,
Vol.66, No.1, hal. 76-84. http://doi.org/10.1016/j.gloplacha.2008.03.011

Hanebuth, Till J. J., Voris, H.K., Yokoyama, Y., Saito, Y. dan Okuno, J. (2011), "Formation and Fate of Sedimentary Depocentres on Southeast Asia's Sunda Shelf over the Past Sea-Level Cycle and Biogeographic Implications", Earth-Science Reviews, Vol.104, No.1, hal. 92-110. http://doi.org/10.1016/j.earscirev.2010.09.006.

Harris B. Stewart, J. (1958), "Sedimentary Reflections of Depositional Environment in San Miguel Lagoon, Baja California, Mexico", AAPG Bulletin, Vol.42, No.11, hal. 2567-2618.

Hesp, P.A., Hung, C.C., Hilton, M., Ming, C.L. dan Turner, I.M. (1998), "A First Tentative Holocene SeaLevel Curve for Singapore", Journal of Coastal Research, Vol.14, No.1, hal. 308-314.

Holbourn, A., Henderson, A.S. dan Norman MacLeod (2013), Atlas of Benthic Foraminifera, 1 Ed., John Wiley \& Sons, Ltd. http://doi.org/10.1002/9781118452493.

Horton, B.P., Gibbard, P.L., Mine, G.M., Morley, R.J., Purintavaragul, C. dan Stargardt, J.M. (2016), "Holocene Sea Levels and Palaeoenvironments, Malay-Thai Peninsula, Southeast Asia:", The Holocene, http://doi.org/10.1191/0959683605hl891rp.

Hunt, D. dan R. L. Gawthorpe (2000), "Sedimentary Responses to Forced Regressions", Geological Society, London, Special Publications, Vol.172, No.1, hal. NP-NP. http://doi.org/10.1144/GSL.SP.2000.172.01.17.

IRUDHAYANATHAN, A., THIRUNAVUKKARASU, R. dan SENAPATHI, V. (2011), GRAIN SIZE CHARACTERISTICS OF THE COLEROON ESTUARY SEDIMENTS, TAMILNADU, EAST COAST OF INDIA - Carpathian Journal of Earth And Environmental Sciences, Vol.6, No.2. Diambil dari

http://www.ubm.ro/sites/CJEES/viewTopic.php ?topicld=166.

Kirci-Elmas, E. (2013), "BENTHIC FORAMINIFERAL DISTRIBUTION (LIVING AND DEAD) FROM A PERMANENTLY STRATIFIED MARGINAL SEA (MARMARA SEA, TURKEY)", Journal of Foraminiferal Research, Vol.43, No.4, hal. 340360. http://doi.org/10.2113/gsjfr.43.4.340.

Lutze, G.F. dan Coulbourn, W.T. (1984), "Recent Benthic Foraminifera from the Continental Margin of Northwest Africa: Community Structure and Distribution", Marine Micropaleontology, Vol.8, No.5, hal. 361-401. http://doi.org/10.1016/0377-8398(84)90002-1.

Malvarez, G.C., Cooper, J.A.G. dan Jackson, D.W.T. (2001), "Relationships Between Wave-Induced 
Currents and Sediment Grain Size on a Sandy Tidal-Flat", Journal of Sedimentary Research, Vol.71, No.5, hal. 705-712. http://doi.org/10.1306/2DC40961-0E47-11D78643000102C1865D.

McLaren, P. dan Bowles, D. (1985), "The Effects of Sediment Transport on Grain-Size Distributions", SEPM Journal of Sedimentary Research, Vol.Vol. 55. http://doi.org/10.1306/212F86FC-2B24-11D78648000102C1865D.

Miall, A.D. (2010), "Historical and Methodological Background", dalam The Geology of Stratigraphic Sequences, eds. Miall, A. D., Springer, Berlin, Heidelberg, hal. 3-45. http://doi.org/10.1007/978-3-642-05027-5_1.

Miall, A.D. (2000), "Stratigraphic Correlation", dalam Principles of Sedimentary Basin Analysis, eds. Miall, A. D., Springer, Berlin, Heidelberg, hal. 79-140. http://doi.org/10.1007/978-3-66203999-1_3.

Morley, R.J. (1982), "A Palaeoecological Interpretation of a 10,000 Year Pollen Record from Danau Padang, Central Sumatra, Indonesia", Journal of Biogeography, Vol.9, No.2, hal. 151-190. http://doi.org/10.2307/2844699.

Newsome, J. dan Flenley, J.R. (1988), "Late Quaternary Vegetational History of the Central Highlands of Sumatra. II. Palaeopalynology and Vegetational History", Journal of Biogeography, Vol.15, No.4, hal. 555-578. http://doi.org/10.2307/2845436.

Nugroho, S. H. (2014), "Sebaran sedimen berdasarkan analisis ukuran butir di Teluk Weda, Maluku Utara", Jurnal Ilmu dan Teknologi Kelautan Tropis, Vol.6, No.1, hal. 229-240.

Nugroho, S.H. (2013), "Kondisi geomorfologi, sedimen permukaan dan aktivitas manusia di kawasan wisata bahari di Desa Morella Dan Negeri Lima, Ambon", Oseanologi dan Limnologi di Indonesia, Vol.39, hal. 263.

Nugroho, S.H. dan Putra, P.S. (2018), "Spatial distribution of grain size and depositional process in tidal area along Waikelo Beach, Sumba", Marine Georesources \& Geotechnology, Vol.36, No.3, hal. 299-307. http://doi.org/10.1080/1064119X.2017.131264 9.

Nugroho, S.H., Putra, P.S., Yulianto, E. dan Noeradi, D. (2018), "Multivariate statistical analysis for characterization of sedimentary facies of Tarakan sub-basin, North Kalimantan", Marine Georesources \& Geotechnology, Vol.36, No.8, hal. 907-917. http://doi.org/10.1080/1064119X.2017.139917 8.
Passega, R. (1964), "Grain Size Representation by CM Patterns as a Geologic Tool", Journal of Sedimentary Research, Vol.34, No.4, hal. 830847. http://doi.org/10.1306/74D711A4-2B2111D7-8648000102C1865D.

Passega, R. dan Byramjee, R. (1969), "Grain-Size Image of Clastic Deposits", Sedimentology, Vol.13, No.3-4, hal. 233-252. http://doi.org/10.1111/j.13653091.1969.tb00171.x.

Phleger, F.B. (1973), "MURRAY, J. W. 1973. Distribution and Ecology of Living Benthic Foraminiferids. Crane Russak \& Co., New York. Xiii + 274 p. \$24.75.", Limnology and Oceanography, Vol.18, No.6, hal. 1011-1011. http://doi.org/10.4319/lo.1973.18.6.1011a.

Posamentier, H. W. dan Kolla, V. (2003), "Seismic Geomorphology and Stratigraphy of Depositional Elements in Deep-Water Settings", Journal of Sedimentary Research, Vol.73, No.3, hal. 367-388. http://doi.org/10.1306/111302730367.

Posamentier, H. W. dan Vail, P.R. (1988), "Eustatic controls on clastic deposition. II. Sequence and systems tract models", dalam Sea Level Changes - An Integrated Approach., SEPM (Society for Sedimentary Geology), hal. 125154.

Posamentier, Henry W. dan Allen, G.P. (1993), "Variability of the Sequence Stratigraphic Model: Effects of Local Basin Factors", Sedimentary Geology, Vol.86, No.1, hal. 91-109. http://doi.org/10.1016/0037-0738(93)90135-R.

Postuma, J.A. (1971), Manual of Planktonic Foraminifera, Diambil dari https://agris.fao.org/agrissearch/search.do?recordID=US201300476228.

Putra, P.S. dan Nugroho, S.H. (2020), Holocene climate dynamics In Sumba Strait, Indonesia: a preliminary evidence from high resolution geochemical records and planktonic foraminifera Studia Quaternaria,.

Putra, P.S. dan Nugroho, S.H. (2017), "Distribusi sedimen permukaan dasar laut Perairan Sumba, Nusa Tenggara Timur", Jurnal Oseanologi dan Limnologi di Indonesia, Vol.2, No.3, hal. 49-63.

Ramamohanarao, T., Sairam, K., Venkateswararao, Y., Nagamalleswararao, B. dan Viswanath, K. (2003), "Sedimentological Characteristics and Depositional Environment of Upper Gondwana Rocks in the Chintalapudi Sub-Basin of the Godavari Valley, Andhra Pradesh, India", Journal of Asian Earth Sciences, Vol.21, No.6, hal. 691-703. http://doi.org/10.1016/S13679120(02)00139-6.

Ramanathan, A., Rajkumar, K., Majumdar, J., Singh, G., Behera, P.N., Santra, S.C. dan Chidambaram, S. 
(2009), "Textural Characteristics of the Surface Sediments of a Tropical Mangrove Sundarban Ecosystem India.", INDIAN J. MAR. SCI., Vol.38, No.4, hal. 7.

Ray, A.K., Tripathy, S.C., Patra, S. dan Sarma, V.V. (2006), "Assessment of Godavari Estuarine Mangrove Ecosystem through Trace Metal Studies", Environment International, Vol.32, No.2, hal. 219-223.

http://doi.org/10.1016/j.envint.2005.08.014.

Saraswat, R. (2015), "Non-Destructive Foraminiferal Paleoclimatic Proxies: A Brief Insight", Proceedings of the Indian National Science Academy, Vol.81, No.2. http://doi.org/10.16943/ptinsa/2015/v81i2/48 094.

Sengupta, B.K. (1977), "Depth distribution of modern benthonic foraminifera on continental shelves of the world Ocean", Indian Journal of Earth Sciences, Vol.4, No.1, hal. 60-83.

Sukapti, W.S. (2016), "Palinologi: Sebuah Teknik Preparasi Mudah dan Aman". Seminar Nasional $X I X$ "Kimia dalam Pembangunan.

Suryantini, S., Ismanto, A. dan Aji, I.K. (2011), "MARINE SEDIMENT CHARACTERISTICS AT KARIMUN JAVA SEA BASED ON STRATIGRAPHIC PROFILE ANALYSIS, TOTAL SUSPENDED SOLID (TSS) AND GRAIN-SIZE ANALYSIS (GRANULOMETRY)", Jurnal IImu dan Teknologi Kelautan Tropis, Vol.3, No.1, hal. 95-101. http://doi.org/10.29244/jitkt.v3i1.7832.

Tjia, H.D. (1996), "Sea-Level Changes in the Tectonically Stable Malay-Thai Peninsula", Quaternary International, Vol.31, hal. 95-101. http://doi.org/10.1016/1040-6182(95)00025-E.

Vail, P. (1991), The Stratigraphic Signatures of Tectonics, Eustacy and Sedimentology - an Overview. Diambil 29 Agustus 2020, dari /paper/Thestratigraphic-signatures-of-tectonics\%2CeustacyVail/8765d1e4582438169f7a2db43ca6e103507 5 deb7.

Vail, P.R. (1987), Seismic Stratigraphy Interpretation Using Sequence Stratigraphy: Part 1: Seismic Stratigraphy Interpretation Procedure, hal. 110.

Van Welzen, P.C., Parnell, J. a. N. dan Slik, J.W.F. (2011), "Wallace's Line and Plant Distributions: Two or Three Phytogeographical Areas and Where to Group Java?", Biological Journal of the Linnean Society, Vol.103, No.3, hal. 531-545. http://doi.org/10.1111/j.10958312.2011.01647.x.

Visher, G.S. (1969), "Grain Size Distributions and Depositional Processes", SEPM Journal of Sedimentary Research, Vol.Vol. 39.
http://doi.org/10.1306/74D71D9D-2B21-11D78648000102C1865D.

Zulhikmah, Yuskar, Y., Putra, P.S., Nugroho, S.H. dan Choanji, T. (2020), "Characteristics of Quaternary Deep Sea Sediment in the Sumba Strait Based on Grain Size and Lol (Lost on Ignition Analysis)", IOP Conference Series: Materials Science and Engineering, Vol.797, hal. $012004 . \quad$ http://doi.org/10.1088/1757899X/797/1/012004.

Zuraida, R., Gerhaneu, N.Y. dan Sulistyawan, I.H. (2018), "KARAKTERISTIK SEDIMEN PANTAI DAN DASAR LAUT DI TELUK PAPELA, KABUPATEN ROTE, PROVINSI NTT", JURNAL GEOLOGI KELAUTAN, Vol.15, No.2. http://doi.org/10.32693/jgk.15.2.2017.376. 